\title{
Slip distribution of the 2007 Bengkulu earthquake inferred from tsunami waveforms and InSAR data
}

\author{
A. R. Gusman, ${ }^{1}$ Y. Tanioka, ${ }^{1}$ T. Kobayashi, ${ }^{1,2}$ H. Latief, ${ }^{3}$ and W. Pandoe ${ }^{4}$ \\ Received 18 March 2010; revised 25 July 2010; accepted 24 August 2010; published 16 December 2010.
}

[1] Joint inversion study using tsunami waveforms and InSAR data provides a new way to understand the magnitude and spatial extent of subduction zone earthquakes. A great earthquake $\left(M_{w} 8.5\right)$ occurred on 12 September 2007 off the west coast of Bengkulu, Indonesia. The tsunami generated by the event was recorded by tide gauge stations around the Indian Ocean and by two bottom-pressure sensors in the deep sea. The ground surface displacements produced by the earthquake on Pagai Islands and on Sumatra Island were observed by Interferometric Synthetic Aperture Radar (InSAR). We estimated the slip distribution of the earthquake by joint inversion incorporating a spatial smoothness constraint, using tsunami waveforms and InSAR data. The total released seismic moment calculated from the slip distribution is $6.7 \times 10^{21} \mathrm{~N} \mathrm{~m}\left(\mathrm{M}_{\mathrm{w}} 8.5\right)$, consistent with the seismic moment of the Global CMT solution, $6.71 \times 10^{21} \mathrm{~N} \mathrm{~m}$. The maximum observed tsunami heights along the coast of Bengkulu agree with those computed from the slip distribution. The slip amount of the 2007 earthquake is smaller than the amount of potential slip that has been accumulated since after the 1797 and 1833 events. The premise is that, averaged over long periods of time, the entire fault must slip equal amounts. Therefore the 2007 great earthquake could be followed by several great earthquakes that will rupture the plate interface until the potential slip that has been accumulated is completely released.

Citation: Gusman, A. R., Y. Tanioka, T. Kobayashi, H. Latief, and W. Pandoe (2010), Slip distribution of the 2007 Bengkulu earthquake inferred from tsunami waveforms and InSAR data, J. Geophys. Res., 115, B12316, doi:10.1029/2010JB007565.

\section{Introduction}

[2] On 12 September 2007 at 11:10:26 UTC, a great earthquake with a moment magnitude $\left(\mathrm{M}_{\mathrm{w}}\right)$ of 8.5 occurred off the west coast of Sumatra Island, about $130 \mathrm{~km}$ southwest off Bengkulu, Indonesia. According to the U.S. Geological Survey (USGS), the epicenter was located at $4.520^{\circ} \mathrm{S}$ and $101.374^{\circ} \mathrm{E}$, between the Sunda trench and the Coast of Sumatra Island (Figure 1). The largest aftershock with $\mathrm{M}_{\mathrm{w}} 7.9$ occurred $12 \mathrm{~h}$ after the main shock. The epicenter of this aftershock is located east of the Pagai Islands (Figure 1).

[3] The 2007 great earthquake occurred within the seismically active Sumatra subduction zone where the IndoAustralian plate is subducting beneath the Sunda plate at an oblique angle. The Mentawai fault, a long linear structure parallel to the Sumatra subduction zone, is located on the west flank of Sumatra fore-arc basin [Diament et al., 1992] but does not appear to be active [Genrich et al., 2000]. The

\footnotetext{
${ }^{1}$ Institute of Seismology and Volcanology, Hokkaido University, Hokkaido, Japan.

${ }^{2}$ Geospatial Information Authority of Japan, Ibaraki, Japan.

${ }^{3}$ Department of Oceanography, Bandung Institute of Technology, Bandung, Indonesia.

${ }^{4}$ Agency of the Assessment and Application of Technology, Jakarta, Indonesia.

Copyright 2010 by the American Geophysical Union. 0148-0227/10/2010JB007565
}

focal mechanism from the Global Centroid Moment Tensor (CMT) catalog shows that the earthquake has a thrust type mechanism with a strike parallel to the trench, indicating that the earthquake occurred on the plate interface between the Indo-Australian plate and the Sunda plate but not at the Mentawai fault.

[4] Along the Sunda trench, a series of megathrust earthquakes has occurred since 2004. The largest among these events, the 26 December 2004 great earthquake $\left(\mathrm{M}_{\mathrm{w}} 9.2\right)$ [Chlieh et al., 2007; Lay et al., 2005; Ammon et al., 2005] caused the most devastating tsunami in the history of countries surrounding the Indian Ocean [Titov et al., 2005; Geist et al., 2007], Indonesia [Borrero, 2005; Jaffe et al., 2006; http:// www.eri.u-tokyo.ac.jp/namegaya/sumatera/surveylog/ eindex.htm], Thailand [Tsuji et al., 2006] Sri Lanka [Goff et al., 2006; Liu et al., 2005], India [Yeh et al., 2007]. Three months later, the 28 March 2005 great earthquake $\left(M_{w} 8.7\right)$ ruptured the plate interface south of the 2004 rupture area [Briggs et al., 2006]. These great earthquakes could be the reactivation on each fault segment where great earthquakes had occurred previously. Paleoseismic evidence suggests that the most recent full-fledged predecessor of the 2004 earthquake occurred about 600 years ago [Jankaew et al., 2008; Monecke et al., 2008]. The 2007 earthquake ruptured the plate interface beneath Mentawai Islands where two historical major events, the $1833\left(\mathrm{M}_{\mathrm{w}}\right.$ 8.9-9.1) and the $1797\left(\mathrm{M}_{\mathrm{w}}\right.$ 8.7-8.9) earthquakes occurred [Newcomb and 


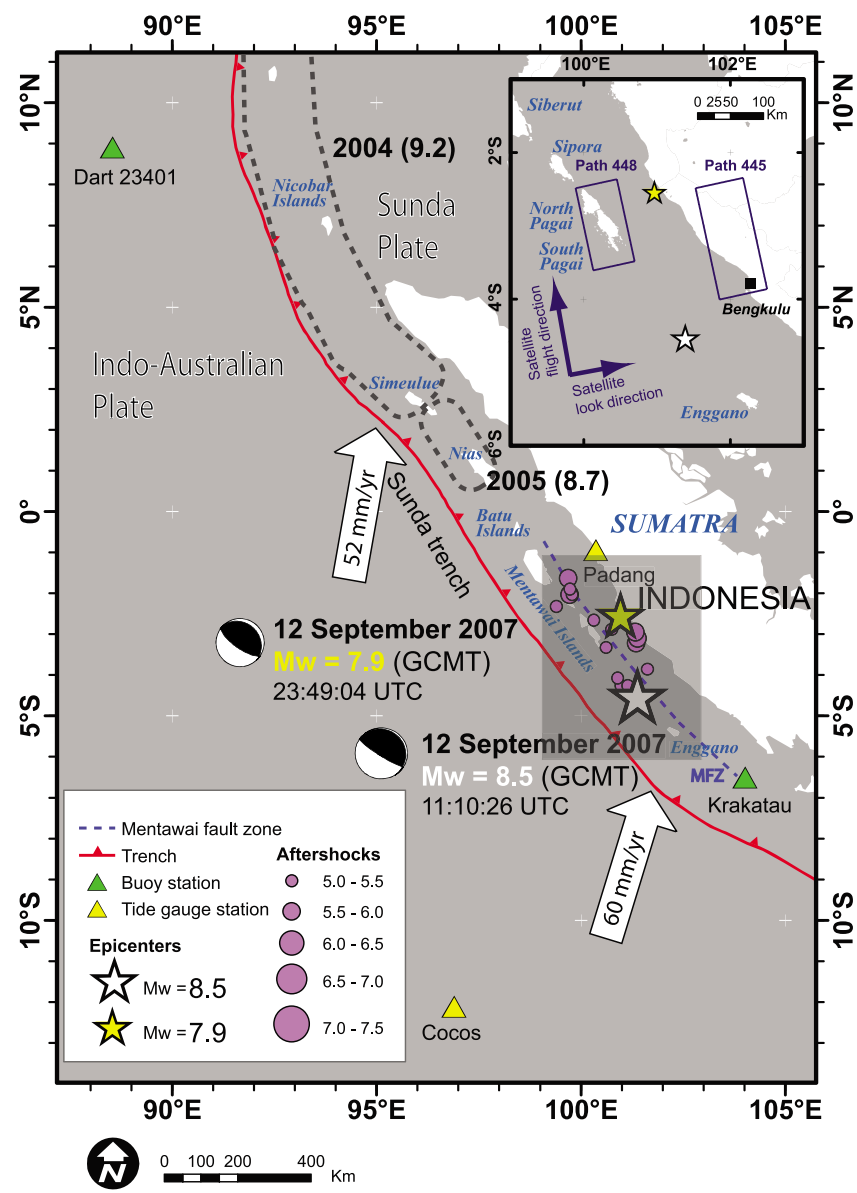

Figure 1. Map of the 2007 Bengkulu earthquake. Epicenter of the main shock $\left(\mathrm{M}_{\mathrm{w}} 8.5\right)$ and the largest aftershock $\left(M_{w}\right.$ 7.9) are represented by white and yellow stars, respectively, and aftershocks are represented by purple circles. Red line is the plate boundary between Sunda plate and Indo-Australian plate, and blue dashed line is the Mentawai fault zone [Diament et al., 1992]. Arrows show relative plate motion vectors [Sieh and Natawidjaja, 2000]. Yellow and green triangles represent tide gauge stations and the buoy stations, respectively. In inset map, blue rectangles show coverage areas of ALOS/PALSAR images which are used to construct interferogram; blue arrows are for satellite flight direction and satellite look direction.

McCann, 1987; Natawidjaja et al., 2006; Chlieh et al., 2008].

[5] Plate tectonics theory provides the kinematic frame work to explain why large earthquakes occur repeatedly along subduction zones [Ruff, 1992]. Geodetic and paleogeodetic measurements along Sumatra subduction zone reveal a heterogeneous coupling where parts of megathrust above $40 \mathrm{~km}$ creep aseismically, whereas others remain locked with a mean interseismic coupling of 0.57 to 0.86 [Chlieh et al., 2008]. Chlieh et al. [2008] used the geodetic data to estimate moment deficit that has been accumulated since the last great earthquakes in 1797 and 1833. The slip amount of the 2007 earthquake is smaller than the amount of potential slip that has been accumulated since the 1797 and 1833 events [Chlieh et al., 2008; Konca et al., 2008; Sieh et al., 2008]. The remains of potential slip must be eventually spent by a single or several future great earthquakes.

[6] A 700-year record of Sumatra megathrust supercycles implies that the 2007 earthquake was the beginning of an episode of large earthquakes on Mentawai Islands [Sieh et al., 2008]. Thus for the purpose of understanding the location and the spatial extent of future great earthquakes that will occur at the unruptured area, it is important to investigate the slip distribution of the 2007 event in detail. By comparing the slip distribution with the rupture area of the historical large earthquakes, the recurrence pattern of large earthquakes in this area can be understood in order to identify the source area of future tsunamigenic earthquakes.

[7] From previous studies by tsunami waveform inversion, the estimated slip distributions of the main shock show that the main slips (9-12 m) occurred at a depth from 20 to $30 \mathrm{~km}$, southeast of South Pagai Island [Lorito et al., 2008, Fujii and Satake, 2008a]. The average rupture velocity inverted from tsunami waveforms for this event is $2.1 \pm$ $0.4 \mathrm{~km} \mathrm{~s}^{-1}$ [Lorito et al., 2008].

[8] Cumulative displacements on the Pagai Islands due to the main shock and the largest aftershock were detected by Interferometric Synthetic Aperture Radar (InSAR) analysis. Konca et al. [2008] estimated slip distributions of the main shock and the largest aftershock events and identified the postseismic effects also by using the InSAR data, coral uplift measurement data and continuous recording GPS (cGPS) data obtained from Sumatra GPS Array (SuGar). The postseismic horizontal displacements during one month following the earthquake for the stations with the largest offsets are less than $10 \%$ of the coseismic offset [Konca et al., 2008].

[9] In this study we estimate the slip distribution of the main shock by performing two different inversions. The first is a tsunami waveform inversion using tsunami waveform data. The tsunami data which are recorded at stations surrounding the source region provide information regarding the spatial extend of rupture area and the overall coseismic slip pattern. The next is a joint inversion using InSAR data in addition to tsunami waveforms. The InSAR data has a dense spatial coverage on the ground deformation in land. Although only the InSAR data poorly constrain the slip distribution around the hypocenter distant from land, the joint inversion using both the tsunami waveforms and InSAR data help constrain the estimated slip distribution.

[10] To test slip distributions inferred from this joint inversion, we used them to compute the coseismic deformation that we equate with the initial sea surface deformation in the near-field tsunami simulations. We then investigate the energy flux of the tsunami off the west coast of Sumatra around the locations where high runups were observed. The simulated tsunami heights along coastline of Sumatra are compared to the measured tsunami runup to test the relation between the slip distribution and runup heights.

\section{Observation Data}

\subsection{Tsunami Waveform Data}

[11] The tsunami generated by the main shock of the 2007 Bengkulu earthquake $\left(M_{w} 8.5\right)$ was recorded by two tide gauge stations at Cocos Islands and Padang (yellow triangles in Figure 1) and two tsunami buoys deployed in the deep ocean northwest Sumatra (DART 23401) and off the Sunda 
Table 1. Location of Tide Gauge Stations and Buoy Stations

\begin{tabular}{llccc}
\hline & Station Name & Type & Longitude $\left({ }^{\circ}\right)$ & Latitude $\left(^{\circ}\right)$ \\
\hline 1 & DART23401 & Buoy & 88.54 & 8.905 \\
2 & Padang & tide gauge & 100.367 & -1 \\
3 & Krakatau Tsunameter & Buoy & 104.016 & -6.512 \\
4 & Cocos Island & tide gauge & 96.9 & -12.7 \\
\hline
\end{tabular}

Strait (Krakatau Tsunameter) (green triangles in Figure 1). The location of the stations are listed in Table 1 and plotted on the map in Figure 1.

[12] The tide gauge data at Padang station have been collected under coordination of the International Oceanographic Data and Information Exchange (IODE) and stored on the Web site of the Vlaams Instituut voor de Zee (http:// www.vliz.be/). The Cocos Islands tide gauge station is operated by the Bureau of Meteorology (BoM), Australian Government. The DART 23401 is deployed in the deep ocean, maintained by the Thai Meteorological Department (TMD) and operated by the National Oceanic and Atmospheric Administration (NOAA), we downloaded the DART data from NOAA's Web site (http://www.ndbc.noaa.gov/). The Krakatau Tsunameter is deployed and maintained by the Agency for the Assessment and Application of Technology (BPPT) Indonesia, the Krakatau Tsunameter data was provided by BPPT.

[13] These tide gauge and buoy records include ocean tides, so we need to remove them to get the tsunami waveforms. First, we approximate the ocean tides by fitting a polynomial function. Then, we remove it from the original records. For the inversion, we use the first cycles of the tsunami waveforms recorded at tide gauges because they contain more information regarding the source properties than the later phases which more contain nonlinear coastal effect. On the other hand, for the buoy records which should not contain much coastal effect, we use several cycles of tsunami waveforms for the inversion. Heights of first cycle of tsunami recorded at Padang, Cocos Islands, DART 23401, and Krakatau Tsunameter are about $1 \mathrm{~m}, 20 \mathrm{~cm}, 4 \mathrm{~cm}$, and $15 \mathrm{~cm}$, respectively.

\subsection{Tsunami Runup Data}

[14] Three days after the earthquake, a post tsunami survey team [Borrero et al., 2009] went to the coastal areas around the city of Bengkulu to measure tsunami flow depth, tsunami height, maximum runup, and inundation distance. The measured runups range between $0.9 \mathrm{~m}$ and $3.9 \mathrm{~m}$, and the maximum runups of $3.9 \mathrm{~m}$ were observed at Lais located about $50 \mathrm{~km}$ to northwest of the city of Bengkulu [Borrero et al., 2009].

\subsection{InSAR Data}

[15] To detect the ground displacement on the Pagai Islands and on the west part of Sumatra Island near the source area, we conduct an InSAR analysis [e.g., Massonnet and Feigl, 1998; Bürgmann et al., 2000]. We use the satellite data of the ALOS/PALSAR, launched in 2006 and operated by Japan Aerospace Exploration Agency (JAXA), which has an L-band sensor with a wavelength of $23.6 \mathrm{~cm}$. The advantage of the L-band sensor is that coherence in interferograms is high even in heavily vegetated areas like in the equatorial area [Bürgmann et al., 2000]. The PALSAR data pairs used in the InSAR analyses are listed in Table 2. The orbital paths 445 and 448 cover the west coastal zone of Sumatra Island and the Pagai Islands, respectively. The perpendicular baseline for each orbital path (Table 2) is so short that high coherence and good interferometric condition for the InSAR analysis can be satisfied [e.g., Zebker and Villasenor, 1992]. These data are the strip map imagery with an incidence angle of $\sim 39^{\circ}$. We removed the topographic phase using SRTM (NASA's Shuttle Radar Topography Mission) data with a 3 arc-sec resolution [Farr et al., 2007]. We process the SAR data from a level-1.0 product using a software package Gamma [Wegmüller and Werner, 1997].

[16] The ground displacement associated with the earthquake on the Pagai Islands is successfully mapped even in the forest areas. Figure 2a shows the interferogram covering the Pagai Islands (path 448). Approximately 14 fringes can be recognized between the south end of the South Pagai Island (Pulau Pagai Selatan) and the north end of the North Pagai Island (Pulau Pagai Utara), indicating that the former has moved $1.7 \mathrm{~m}$ toward the satellite relative to the latter.

[17] A significant ground deformation in the coastal zone of Sumatra Island (Figure 2b) is also identified. The maximum displacement toward the satellite relative to the southeastern edge can be recognized with approximate $40 \mathrm{~cm}$ at the region showing roundish-shaped fringes.

\section{Method}

\subsection{Tsunami Numerical Simulation}

[18] The bathymetry data sets used for tsunami simulation are based upon the GEBCO bathymetry data set and nautical charts of Cocos Islands and Padang. The nautical charts give more accurate bathymetry around Cocos Islands and near Padang where the tide gauges are located. Because the GEBCO data set has a poor accuracy on shallow water regions, we need to digitize the nautical charts for tsunami simulation.

[19] The computational area ranges from $86^{\circ} \mathrm{E}$ to $106^{\circ} \mathrm{E}$ and from $12^{\circ} \mathrm{N}$ to $15^{\circ} \mathrm{S}$. We use different grid sizes of 3 arcminute (approximately $5.5 \mathrm{~km}$ ), 1 arc-minute (approximately $1.8 \mathrm{~km}$ ), 20 arc-second (approximately $600 \mathrm{~m}$ ), and 6.7 arcsecond (approximately $200 \mathrm{~m}$ ) to compute the tsunami. We use the finest grids for near coastal area around Cocos Islands and Padang tide gauge stations. Nested grid system is used to connect between small grid system and large grid system.

[20] Synthetic tsunami waveforms (Figure 3c) at the four stations from all subfaults are numerically computed using the finite different scheme. Governing equations for the far field tsunami computation are the following. We take the spherical coordinate system $(r, \theta$, and $\varphi)$ with the origin at the Earth's center. The Earth is assumed as a sphere, so $r$ is constant and equal to the Earth's radius $R$. The linear shallow

Table 2. ALOS/PALSAR Data Used in This Study ${ }^{\mathrm{a}}$

\begin{tabular}{ccccc}
\hline Path & $\begin{array}{c}\text { Flight } \\
\text { Direction }\end{array}$ & $\begin{array}{c}\text { Master Image } \\
{[\text { Mode] }}\end{array}$ & $\begin{array}{c}\text { Slave Image } \\
{[\text { Mode] }}\end{array}$ & $\begin{array}{c}\text { Bperp } \\
(\mathrm{m})\end{array}$ \\
\hline 445 & ascending & 29 Jan 2007 [FBS] & 16 Sep 2007 [FBD] & -134 \\
448 & ascending & 21 Jun 2007 [FBD] & 21 Sep 2007 [FBD] & -280 \\
\hline
\end{tabular}

${ }^{\mathrm{a}} \mathrm{FBS}$ and FBD indicate fine-beam single polarization and a fine-beam dual polarization, respectively, which are observation modes handled by ALOS/PALSAR. Bperp stands for a perpendicular baseline. 
a)

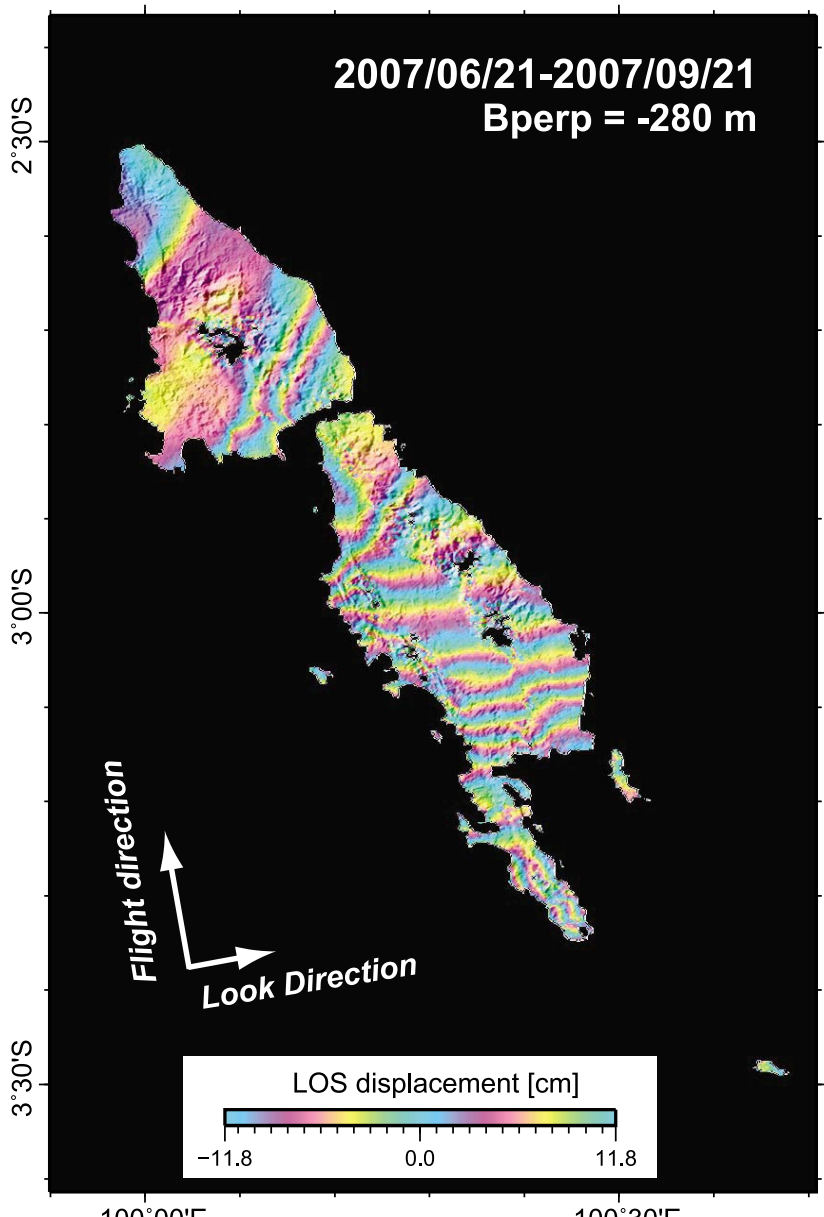

b)

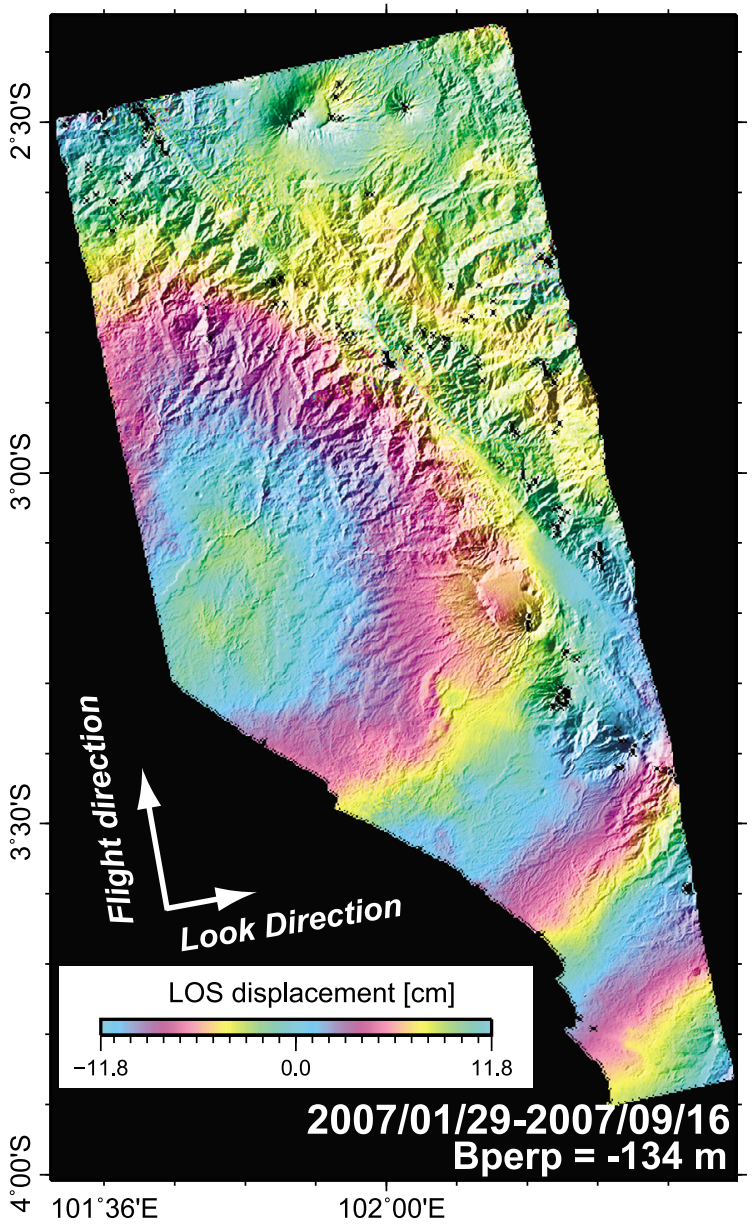

Figure 2. Displacement in line-of-sight (LOS) direction (a) on Pagai Islands (path 448) with 3 months of time spans and (b) on Sumatra (path 445) with 8 months of time spans. One color cycle represents $11.8 \mathrm{~cm}$ range change. The arrows represent the satellite flight direction on the orbit and the satellite look direction.

water or the linear long wave theory is given by the following equations [Johnson, 1999]:

$$
\begin{gathered}
\frac{\partial h}{\partial t}+\frac{1}{R \sin \theta}\left[\frac{\partial}{\partial \theta}\left(Q_{\theta} \sin \theta\right)+\frac{\partial Q_{\varphi}}{\partial \varphi}\right]=0 \\
\frac{\partial Q_{\varphi}}{\partial t}=-f Q_{\theta}-\frac{g d}{R \sin \theta} \frac{\partial h}{\partial \varphi} \\
\frac{\partial Q_{\theta}}{\partial t}=f Q_{\varphi}-\frac{g d}{R} \frac{\partial h}{\partial \theta}
\end{gathered}
$$

In the above equations, $\varphi$ is longitude, $\theta$ is colatitude $\left(90^{\circ}-\right.$ latitude), $f$ is the Coriolis coefficient, $t$ is time, $h$ is the water level, $Q_{\varphi}$ and $Q_{\theta}$ are the flow flux along latitude and longitude axes, respectively, $g$ is the gravitational acceleration, and $d$ is the water depth. The Coriolis coefficient is given by $f=$ $2 \Omega \cos \theta$, where $\Omega$ is the angular frequency of the Earth's rotation. The open boundary condition at the edge of the computational area and the total reflection boundary at the shoreline are used for the computation. Computational time step of $1 \mathrm{~s}$ is chosen to satisfy Courant-Friedrichs-Lewy (CFL) stability condition that is expressed by the following equation:

$$
\Delta t \leq \frac{\Delta x}{\sqrt{2 g d}}
$$

The physical meaning of the stability condition is that the time step $\Delta t$ must be equal or smaller than the time required for the wave to propagate the spatial grid size $\Delta x$.

[21] The equations of energy flux vector along E-W direction $\left(E_{x}\right)$ and $\mathrm{N}-\mathrm{S}$ direction $\left(E_{y}\right)$ described by Kowalik et al. [2008] are

$$
\begin{aligned}
& E_{x}=\rho d u\left[g h+\frac{1}{2}\left(u^{2}+v^{2}\right)\right] \\
& E_{y}=\rho d v\left[g h+\frac{1}{2}\left(u^{2}+v^{2}\right)\right]
\end{aligned}
$$


(a)

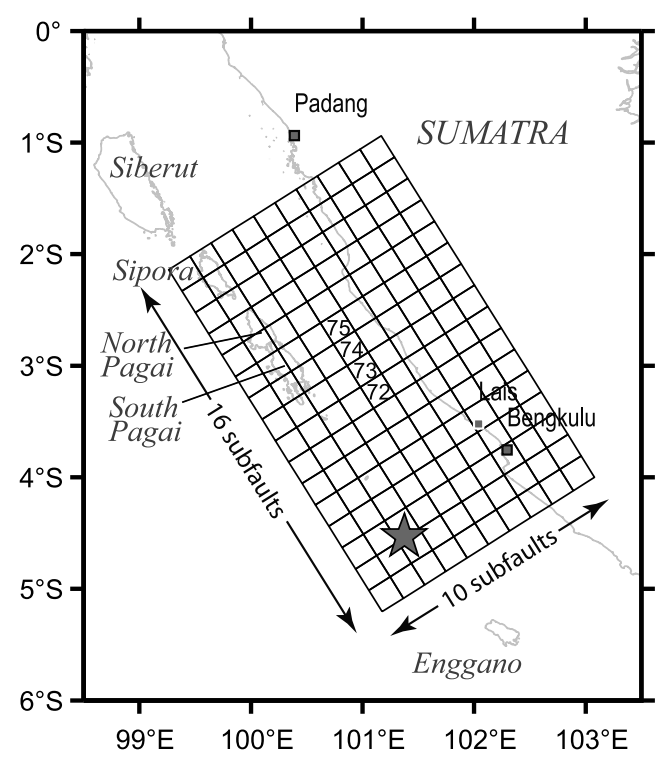

(b)

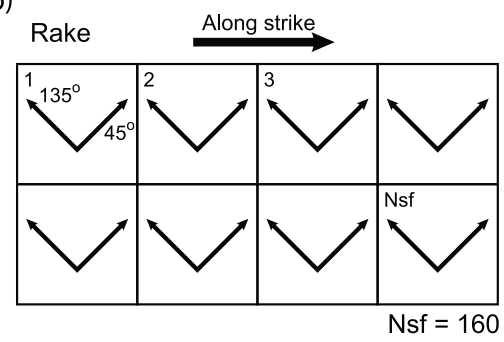

(c)

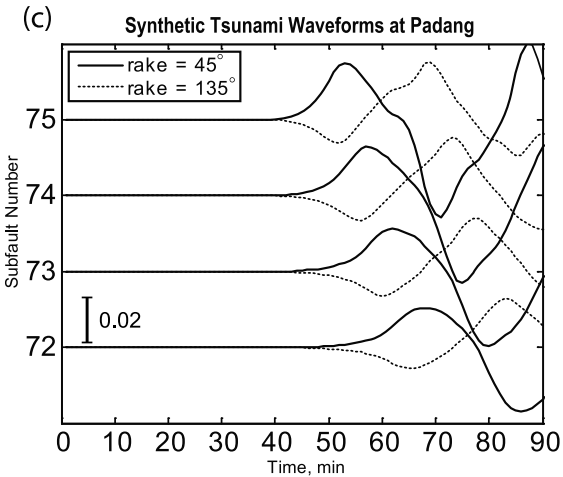

Figure 3. (a) Subfaults we used to estimate the slip distribution of the 2007 great earthquake. The size of each patch is $25 \mathrm{~km} \times 25 \mathrm{~km}$. (b) Diagram showing that two rake values are used on each subfault. (c) Sample of synthetic tsunami waveforms at Padang simulated using subfault number 72 to 75.

where $u$ and $v$ are components of velocity along $\mathrm{x}$ and $\mathrm{y}$ directions, respectively, $d$ is the water depth, $h$ is the water level, and $g$ is the gravitational acceleration. The seawater density $\rho$ is assumed to be $1027 \mathrm{~kg} \mathrm{~m}^{-3}$.

[22] The linear shallow water equations are numerically solved to compute synthetic tsunami waveforms at the buoy stations and the tide gauge stations. Because tsunami on the deep ocean is not affected by coastal effects, simulation of the tsunami using the linear shallow water equations is widely accepted [Synolakis et al., 2008]. First cycle of tsunami waveform recorded at tide gauge station contains only little nonlinear effect. First cycle of tsunami waveforms have been used in tsunami waveform inversions from which many source process of great earthquakes are estimated in AlaskaAleutians [e.g., Johnson, 1999], Japan [e.g., Satake, 1989; Tanioka et al., 1995; Baba and Cummins, 2005], Kuril Islands [e.g., Fujii and Satake, 2008b], Sumatra [e.g., Fujii and Satake, 2007, 2008a; Lorito et al., 2008].

\subsection{InSAR Data Processing for Inversion Analysis}

[23] The satellite image used to construct the interferogram on the Pagai Islands was acquired 9 days after the main shock. The interferogram includes ground displacements caused by coseismic deformation due to the main shock as well as the aftershocks and their postseismic deformation that must have lasted during the first 9 days after the main shock. In this study, we need only the coseismic deformation due to the main shock.

[24] Since the epicenter of the largest aftershock is close to the Pagai Islands, the deformation caused by this event might contaminate the interferogram. Therefore the effect of the surface displacement caused by the $\mathrm{M}_{\mathrm{w}} 7.9$ event, computed from a slip distribution estimated by Konca et al. [2008], is eliminated from the original interferogram.
[25] For the inversion analysis, we resample the interferogram data beforehand using a quadtree decomposition method [Samet and Webber, 1988; Jónsson et al., 2002]. A square image is divided into four equal-sized square blocks if the maximum value minus the minimum value in the square is larger than a threshold. We give the threshold as $3 \mathrm{~cm}$ and $2 \mathrm{~cm}$ to the path 445 and path 448 data, respectively. This process is repeated iteratively until each block meets the criterion. Through the partitioning procedure, the resultant numbers of data points for the path 445 and path 448 are reduced from 148,218 to 2860 and from 94,439 to 4341 , respectively.

\subsection{Inversion Method}

[26] We assume a ruptured fault plane with a length of $400 \mathrm{~km}$ and a width of $250 \mathrm{~km}$ by referring to the aftershock distribution. We then divide the fault plane into 160 subfaults with a uniform size of $25 \mathrm{~km} \times 25 \mathrm{~km}$ (Figure $3 \mathrm{a}$ ). The focal mechanism of strike $328^{\circ}$ and dip $9^{\circ}$, obtained from the Global CMT solution of the main shock, is assumed for all the subfaults. In this study, we use rake angles of $45^{\circ}$ and $135^{\circ}$ for each subfault (Figure $3 \mathrm{~b}$ ) to estimate the slip direction of each subfault.

[27] The initial sea-surface deformation is assumed to be equal to the coseismic deformation on the ocean bottom. The deformation on the ocean bottom is computed for each subfault with unit amount of slip using Okada [1985] formula.

[28] In previous studies by tsunami waveform inversion [e.g., Satake, 1989; Fujii and Satake, 2008a; Lorito et al., 2008], the tsunami waveform has been used to determine the slip amount with a fixed rake value. In this study, we propose a new approach in tsunami waveform inversion that determines both slip amount and direction. Figure $3 \mathrm{c}$ shows 
(a)
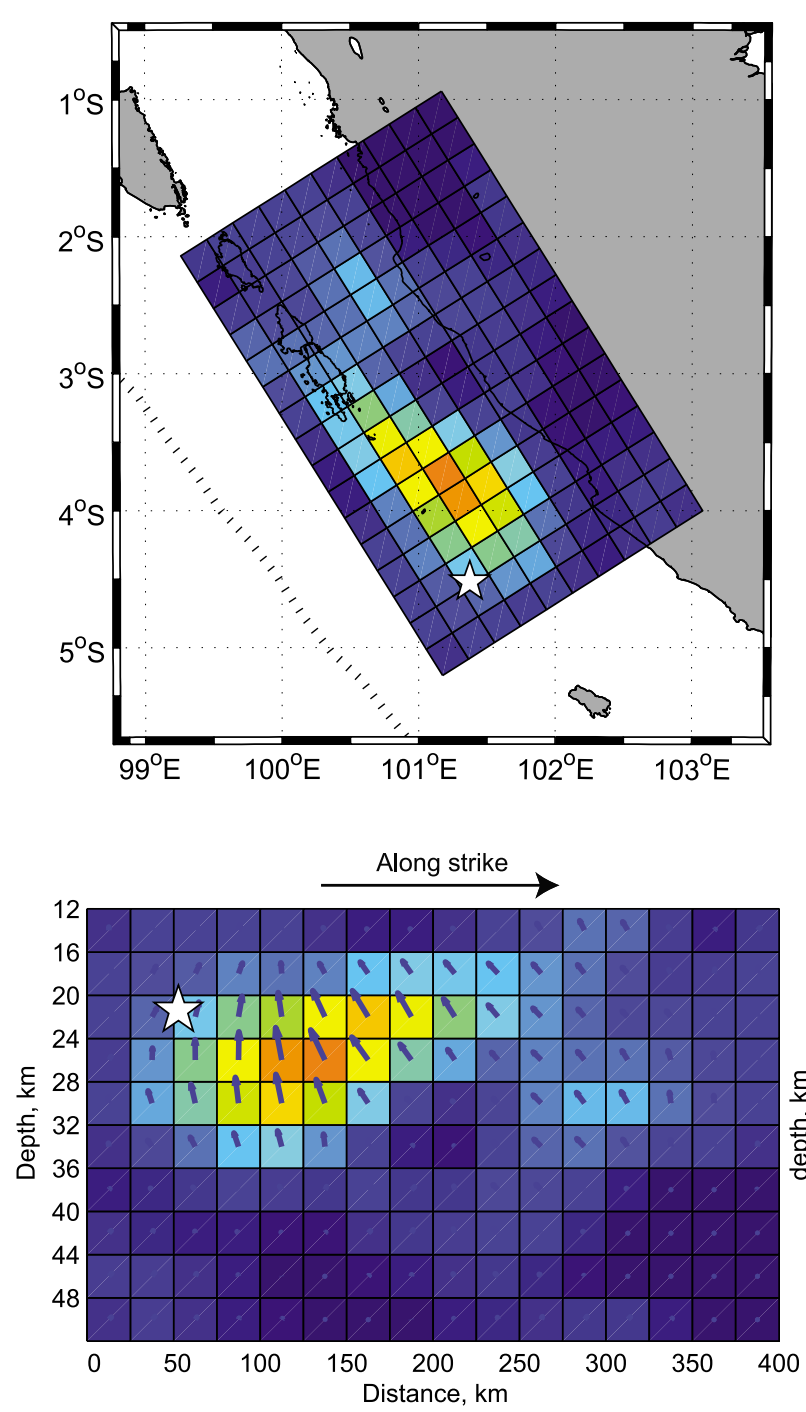

Standard Error

(Tsunami Inversion)

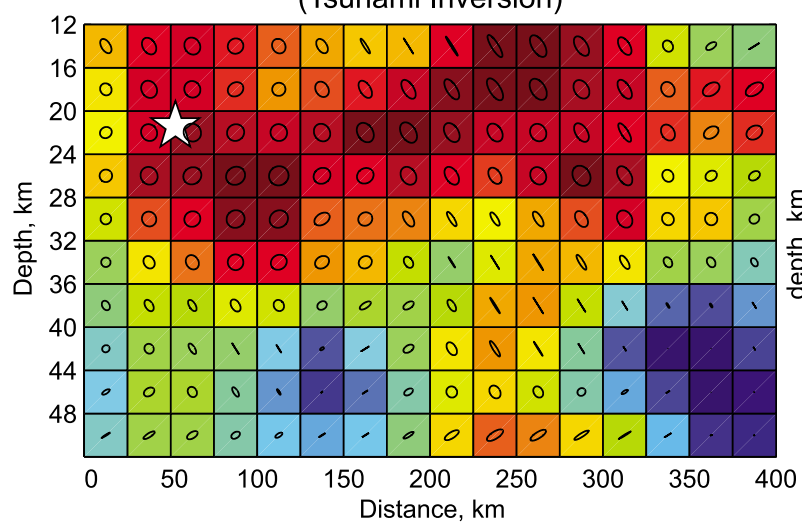

(b)
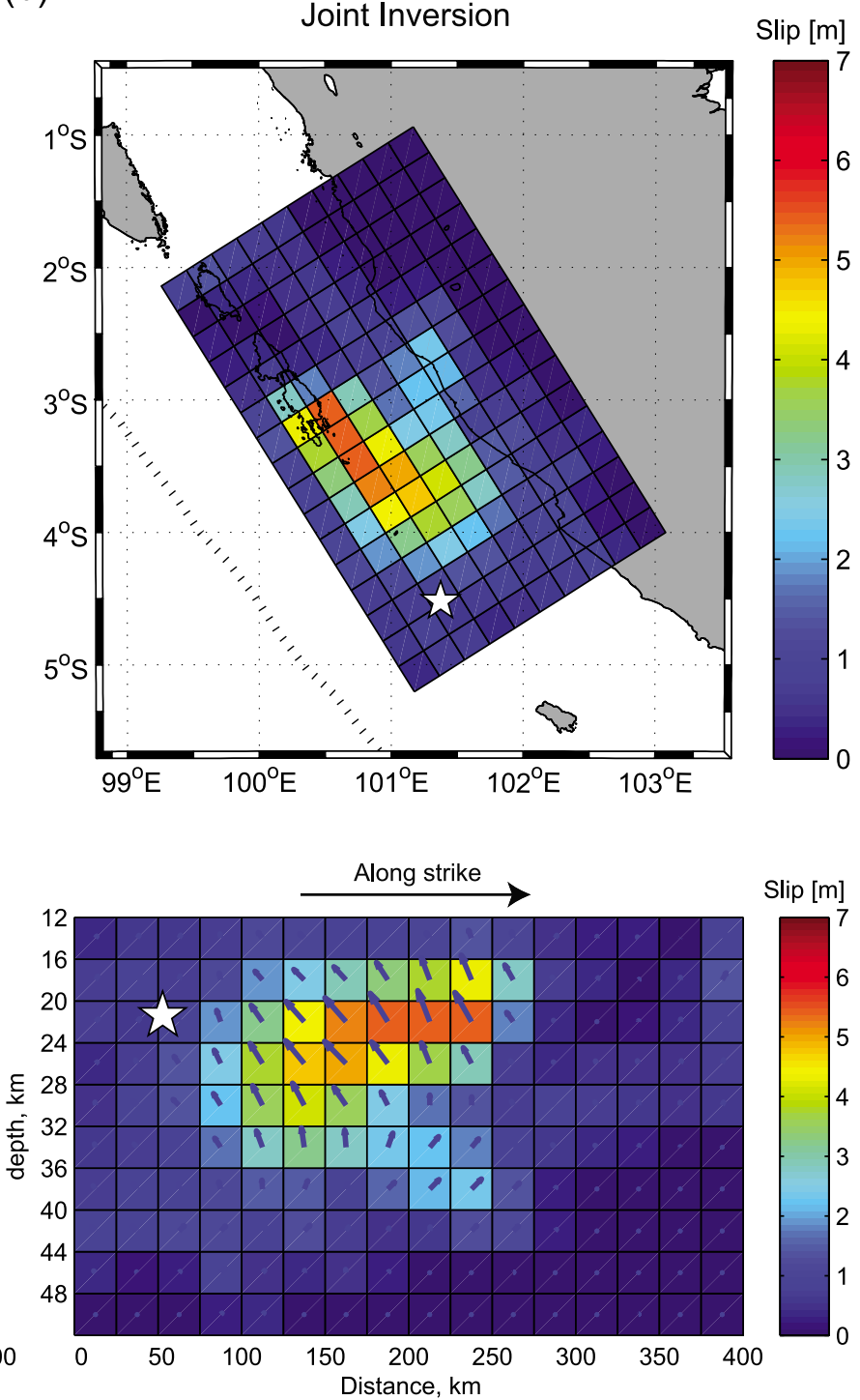

Slip [m]

Standard Error

(Joint Inversion)

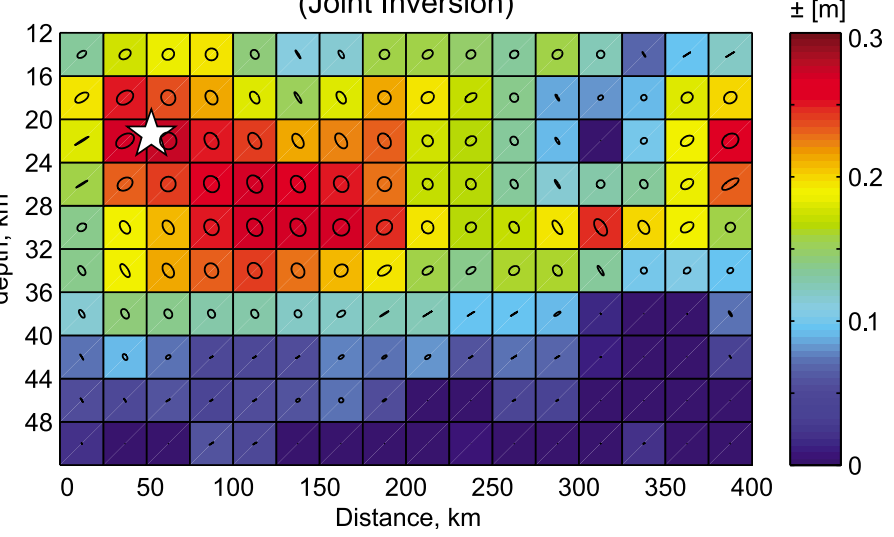

Figure 4. Slip distribution of the main shock of the 2007 Bengkulu earthquake (a) estimated from only tsunami waveform data and (b) estimated by the joint inversion using both tsunami waveforms and InSAR data. The smoothing factor $\left(\alpha^{2}\right)$ is fixed at 0.5. Standard error for the slip distribution estimated by the tsunami waveform inversion, and joint inversion are shown in the bottom. Ellipses are errors for the estimated rake angle on each subfault. 


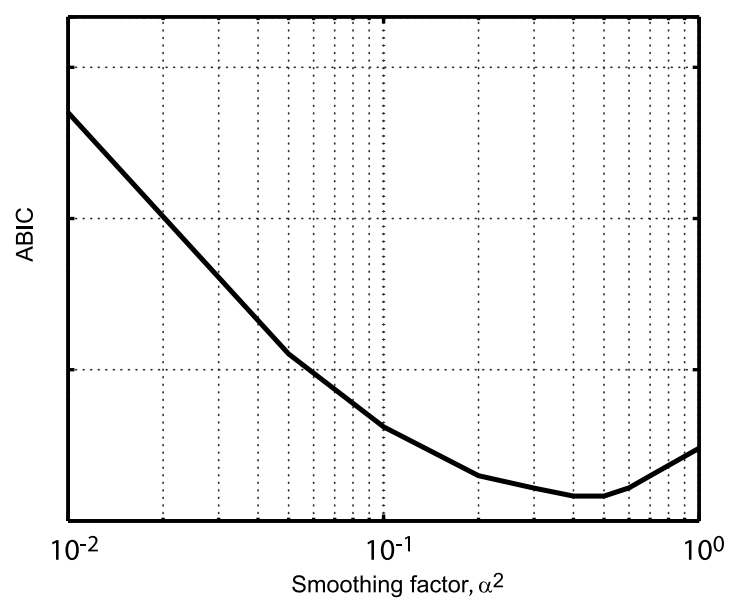

Figure 5. Values of ABIC plotted as a function of $\alpha^{2}$. The ABIC is minimized at $\alpha^{2}=0.5$.

the difference between two synthetic tsunami waveforms which are generated by an unit amount of slip on four subfaults, $72,73,74$, and 75 , with different rake angles of $45^{\circ}$ and $135^{\circ}$. The fault model with rake angle of $45^{\circ}$ generates synthetic tsunami waveforms at Padang with positive wave front, while that with the rake angle of $135^{\circ}$ generates synthetic tsunami waveforms with negative wave front. This difference between two synthetic tsunami waveforms indicates that there is a resolution to estimate rake angle on the subfault using tsunami waveforms. The slip amounts for both rake angles on the subfault can be estimated by solving an inversion procedure. Then a slip amount and a slip direction on the subfault are calculated by vector addition using the inverted slip amounts as the vector's magnitudes and the rake angles of $45^{\circ}$ and $135^{\circ}$ as vector's directions. In this new approach, the number of parameters is twice than in the conventional approach in tsunami waveform inversion. The procedure to determine the rake angle on subfault is used in a way similar to that where seismic waves are used [e.g., $J i$ et al., 2002; Lay et al., 2010].

[29] Since the amplitude of observed tsunami waveforms varies from a few centimeters to a meter at different stations, we normalize the tsunami waveforms by the height of the first tsunami cycles recorded at Padang tide gauge station. The height recorded at Padang station is the highest among other records.

[30] The spatial variation of fault slip must be smooth in some degree because of the finiteness in the fracture strength of actual rocks [Yabuki and Matsu'ura, 1992]. The increase in model parameters may also increase instability of the solution. Therefore we incorporate a spatial smoothness constraint on the slip distribution into the inversion procedure. We used the following objective function, minimized in the inversion

$$
s(\mathbf{m})=\lambda^{2}(\mathbf{d}-\mathbf{G m})^{t} \mathbf{E}^{-1}(\mathbf{d}-\mathbf{G m})+\alpha^{2} \mathbf{m}^{t} \mathbf{H m}
$$

where $\boldsymbol{\lambda}$ is weight, $\mathbf{d}$ is the observed tsunami waveforms in the tsunami waveform inversion, and both observed tsunami waveforms and InSAR data in the joint inversion, $\mathbf{G}$ is the Green's function contains the synthetic tsunami waveforms in the tsunami waveform inversion, and both synthetic tsunami waveforms and displacement in line-of-sight (LOS) direction in the joint inversion, $\mathbf{m}$ is the model parameter vector, $\alpha^{2}$ is a smoothing factor, $\mathbf{H}$ is a smoothing matrix consisting of a Laplacian operator that spatially smooths the slip distribution, and $\mathbf{E}$ is the measurement errors which is assumed to be the covariance matrix of the data.

[31] To determine the optimal value of the smoothing factor $\left(\alpha^{2}\right)$, we use Akaike's Bayesian information criterion (ABIC) proposed by Akaike [1980]. We may express the ABIC as it described by Yabuki and Matsu'ura [1992] in the form of

$$
\begin{aligned}
A B I C\left(\alpha^{2}\right)= & (N+P-M) \log s(\mathbf{m})-P \log \alpha^{2} \\
& +\log \left\|\mathbf{G}^{t} \mathbf{E}^{-1} \mathbf{G}+\alpha^{2} \mathbf{H}\right\|+C
\end{aligned}
$$

where $N$ is total number of data points of the tsunami waveforms, $P$ is number of subfaults multiplied by two (we apply two rake values for each subfault), $M$ is number of model parameters, and $C$ is a constant. The search for the value of $\alpha^{2}$ is carried out by an iterative process, in which $\alpha^{2}$ that gives a minimum ABIC is regarded as the optimal value.

[32] To know how good the estimated slip distribution is, we evaluate its standard error using "delete-half” Jackknife technique [Tichelaar and Ruff, 1989]. A “delete-half” Jackknife resample is extracted from the original data by deleting half the number of data points. We calculate the standard error of the best estimated slip distribution using 50 model estimates from the "delete-half" Jackknife resamples.

\section{Results}

\subsection{Slip Distribution Determined by the Tsunami Waveform Inversion}

[33] The slip distribution inverted only from the tsunami waveform data is shown in Figure 4a. The optimal value of smoothing factor $\left(\alpha^{2}\right)$ that minimizes the value of ABIC is 0.5 (Figure 5). The major slip region is located on a depth between $16 \mathrm{~km}$ and $36 \mathrm{~km}$ with the maximum slip amount of $\sim 5 \mathrm{~m}$ (Figure $4 \mathrm{a}$ ). The average estimated rake value for the slip distribution is $108^{\circ}$. Figure 6 a shows that the simulated tsunami waveforms agree well with the observed ones.

[34] The seismic moment calculated from our slip distribution is $7.0 \times 10^{21} \mathrm{~N} \mathrm{~m}\left(\mathrm{M}_{\mathrm{w}} 8.5\right)$ by assuming the rigidity of $4 \times 10^{10} \mathrm{~N} \mathrm{~m}^{-2}$ for shallower subfaults and $7 \times 10^{10} \mathrm{~N} \mathrm{~m}^{-2}$ for deeper subfaults (Table 3 ).

\subsection{Slip Distribution Determined by the Joint Inversion}

[35] The tsunami waveform inversion result suggests that large amounts of slip occurred as much as $150 \mathrm{~km}$ from the hypocenter. The dense spatial coverage of the InSAR data in the Pagai Islands provides heightened resolution of slip distribution beneath them. To improve the spatial resolution of slip distribution near the island, we now perform a joint inversion using InSAR data in addition to tsunami data.

[36] In the joint inversion, the InSAR data on Pagai Islands, the InSAR data on Sumatra Island, and the tsunami waveforms are weighted by the $\frac{1}{\sigma}$, where $\sigma$ is the standard deviation of the data. The weights of tsunami waveforms, 
(a)

Tsunami Inversion

DART 23401
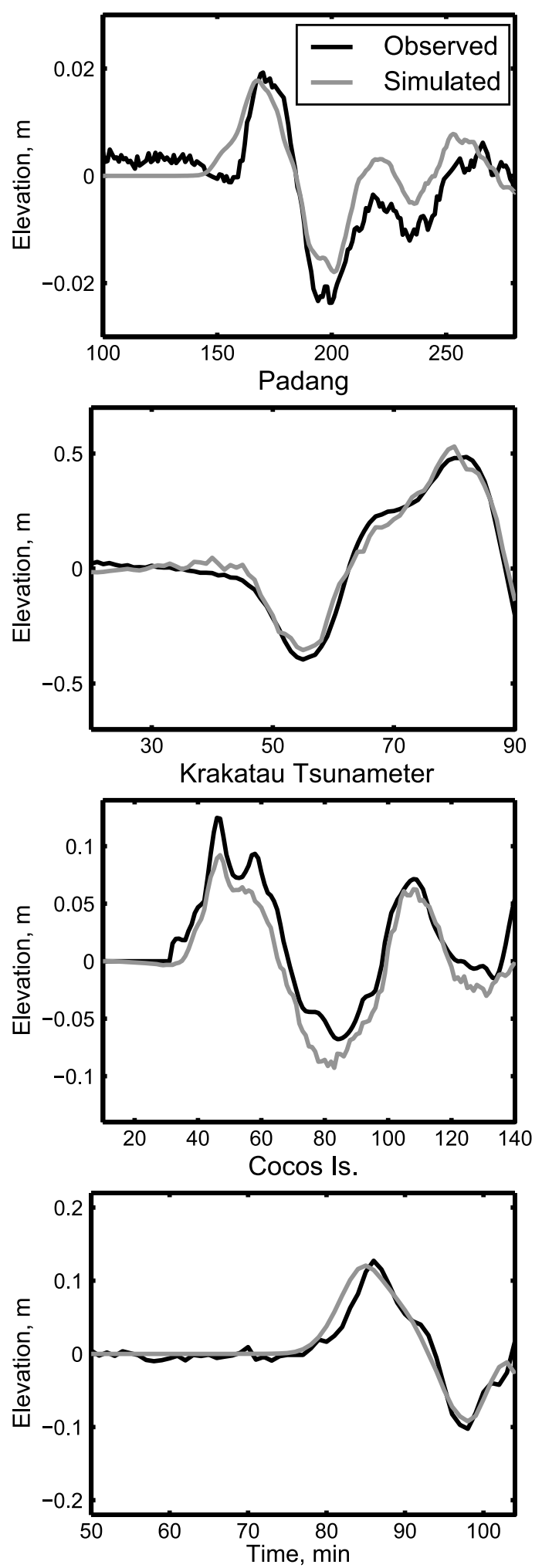

(b)
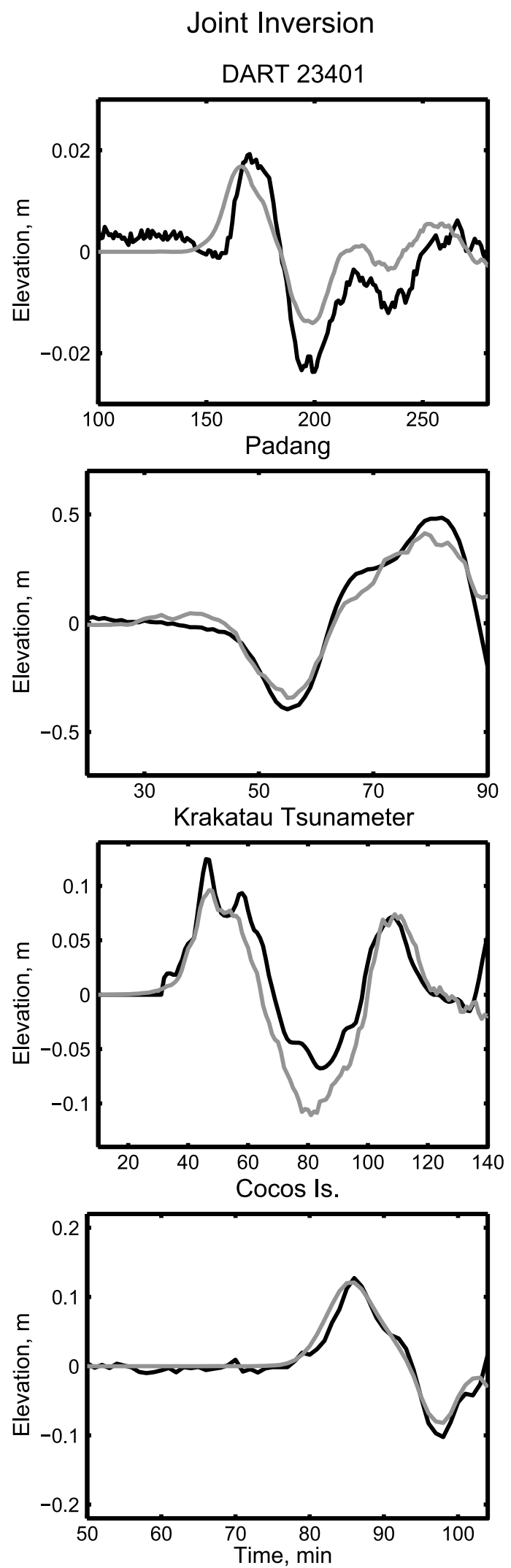

Figure 6. Comparisons of the observed tsunami waveforms with the simulated ones for (a) tsunami waveform inversion and (b) joint inversion. The black lines represent the observed tsunami waveforms. The gray lines represent the simulated tsunami waveforms. 
Table 3. Depth and Rigidity of the Subfaults

\begin{tabular}{lcc}
\hline Subfaults & Depth $(\mathrm{km})$ & Rigidity $\left(\mathrm{N} \mathrm{m}^{-2}\right)$ \\
\hline $1-16$ & 12 & $4 \times 10^{10}$ \\
$17-32$ & 16 & $4 \times 10^{10}$ \\
$33-48$ & 20 & $4 \times 10^{10}$ \\
$49-64$ & 24 & $7 \times 10^{10}$ \\
$65-80$ & 28 & $7 \times 10^{10}$ \\
$81-96$ & 32 & $7 \times 10^{10}$ \\
$97-112$ & 36 & $7 \times 10^{10}$ \\
$113-128$ & 40 & $7 \times 10^{10}$ \\
$129-144$ & 44 & $7 \times 10^{10}$ \\
$145-160$ & 48 & $7 \times 10^{10}$ \\
\hline
\end{tabular}

InSAR data on Pagai Island, and InSAR data on Sumatra Island are $1,0.3$, and 2.5 , respectively. To estimate the slip distribution, we use the same smoothing factor $\left(\alpha^{2}\right)$ of 0.5 as the value that determined for the tsunami waveform inversion. We compare two slip distributions estimated by the tsunami waveform inversion and the joint inversion. The slip distribution estimated by the joint inversion has larger slip amounts on the major slip region. In the major slip region estimated by the joint inversion, the maximum slip is located south east of the Pagai Islands with a value exceeding $5 \mathrm{~m}$ (Figure 4b). The slip amounts and the rake values of each

\section{(a) InSAR data}

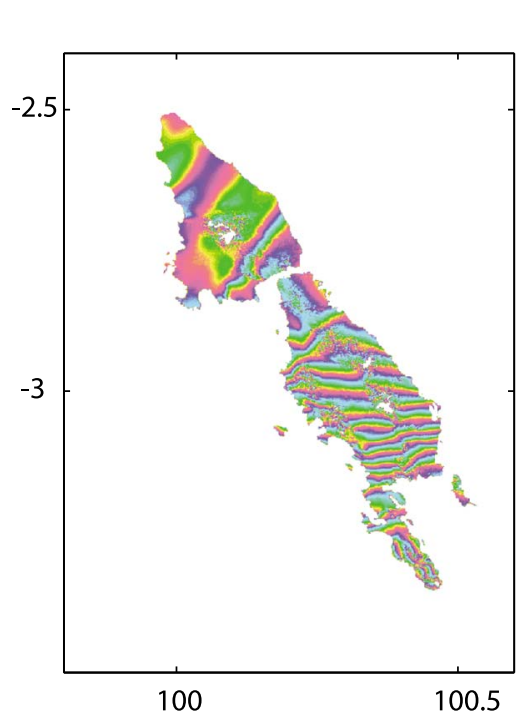

(b) Model: Tsunami Inversion

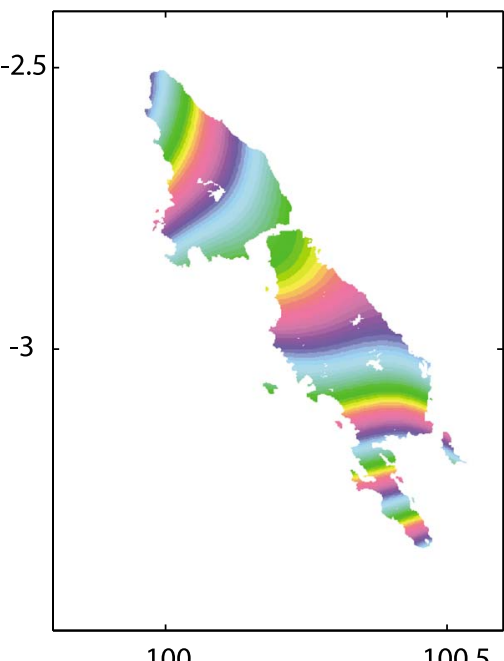

(d) Residual: Tsunami Inversion

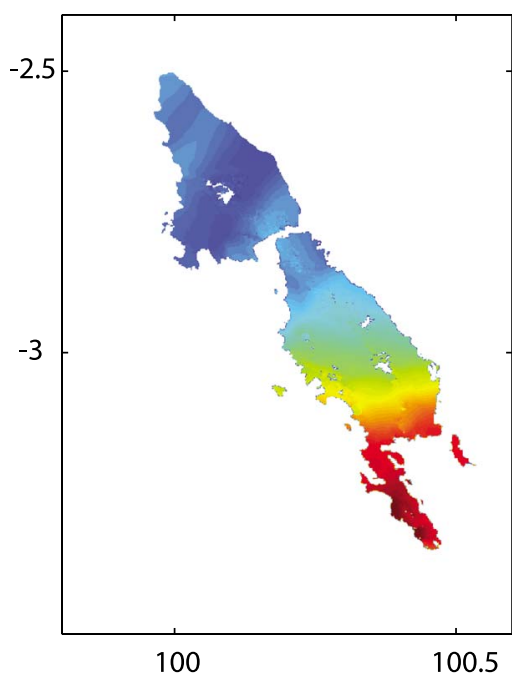

(c) Model: Joint Inversion

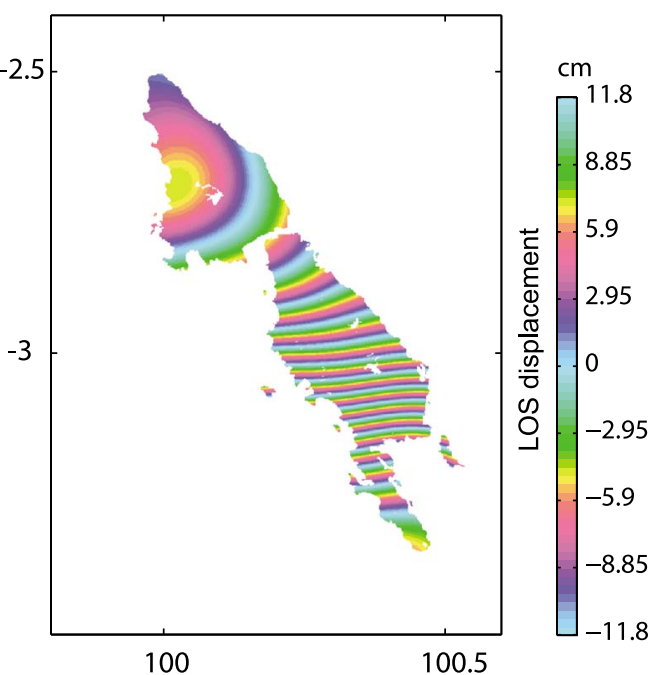

(e) Residual: Joint Inversion

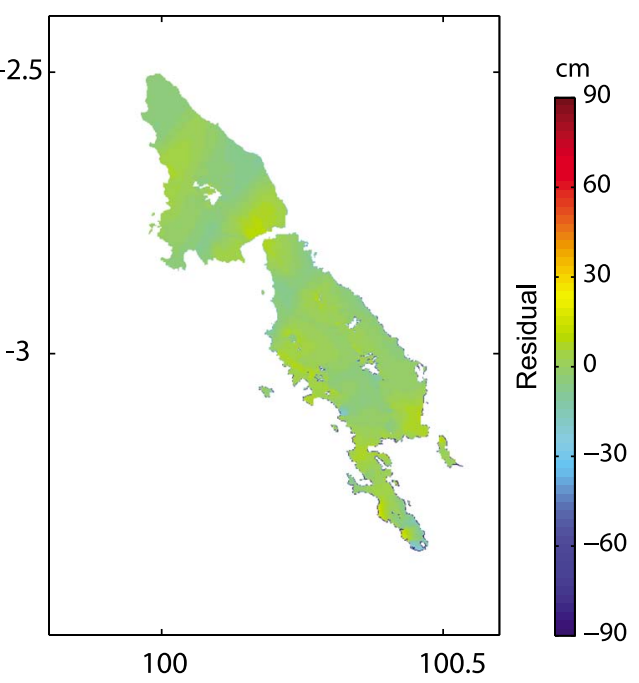

Figure 7. (a) The interferogram where the effect from the largest aftershock (Mw 7.9) [Konca et al., 2008] is eliminated from the original interferogram (Figure 2a). (b) LOS displacement calculated from the result of the tsunami waveform inversion. (c) LOS displacement calculated from the result of the joint inversion. (d) Residue of displacement in LOS direction calculated from the result of the tsunami waveform inversion. (e) Residue of displacement in LOS direction calculated from the result of the joint inversion. 
(a) InSAR data

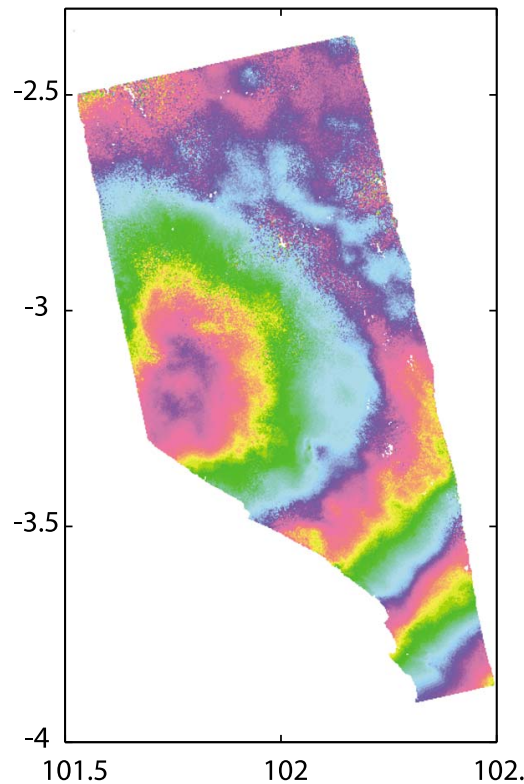

(b) Model:

Tsunami Inversion

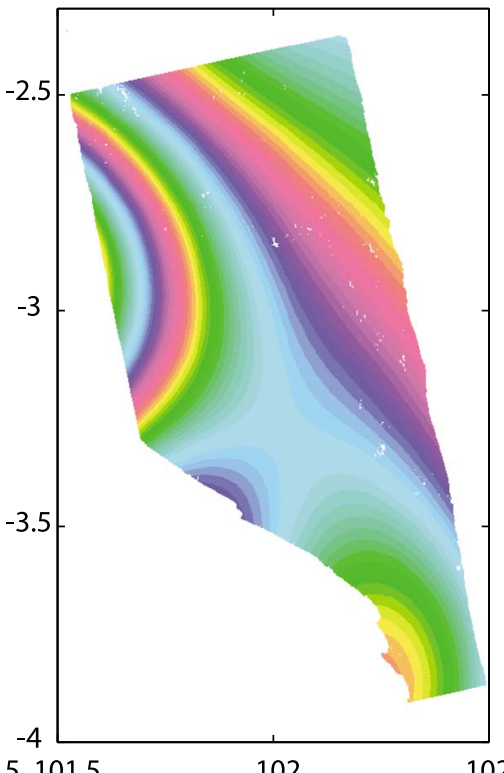

(d) Residual:

Tsunami Inversion

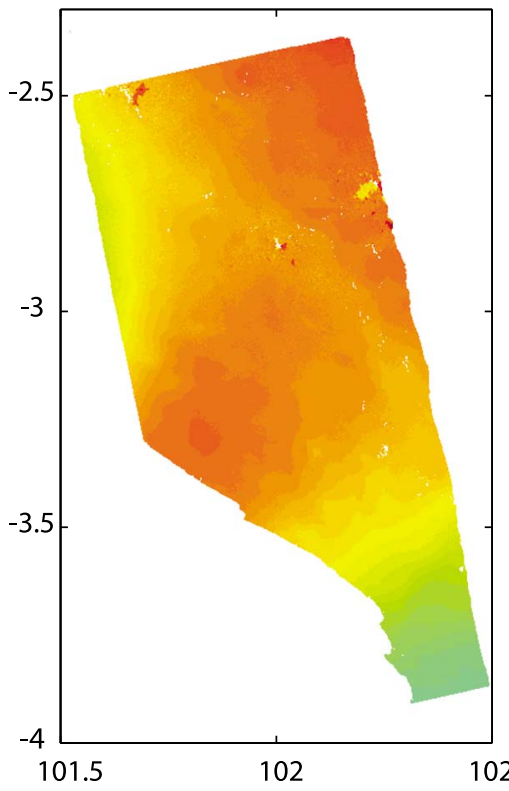

(c) Model: Joint Inversion

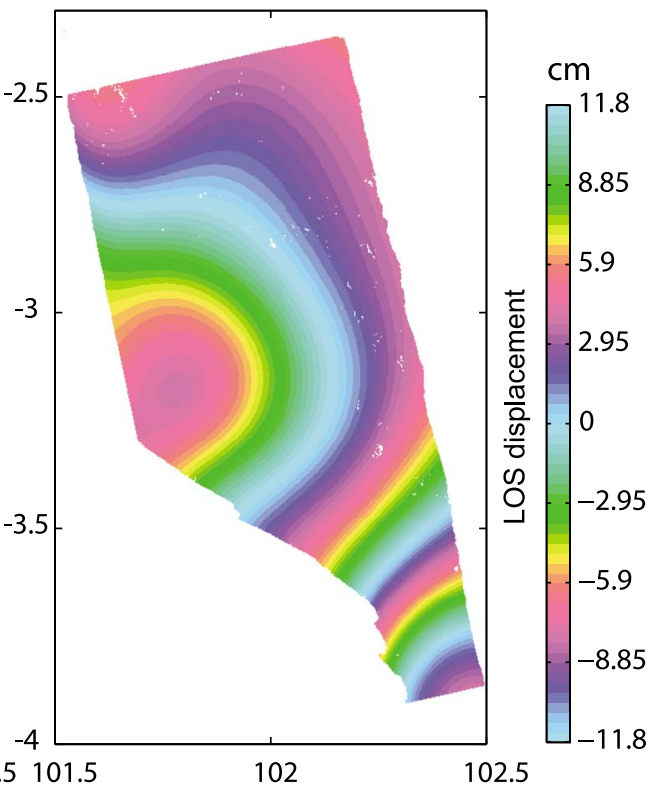

(e) Residual: Joint Inversion

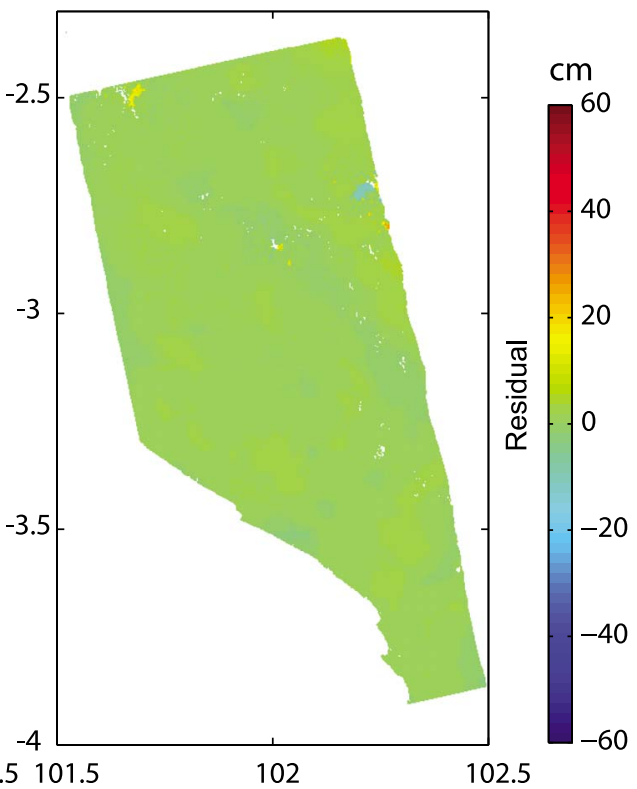

Figure 8. (a) InSAR data on Sumatra Island. (b) LOS displacement calculated from the result of the tsunami waveform inversion. (c) LOS displacement calculated from the result of the joint inversion. (d) Residue of displacement in LOS direction calculated from the result of the tsunami waveform inversion. (e) Residue of displacement in LOS direction calculated from the result of the joint inversion.

subfault estimated by the tsunami waveform inversion and the joint inversion are listed in Table S1. ${ }^{1}$

[37] The released seismic moment calculated from the slip distribution estimated by the joint inversion is $6.7 \times 10^{21} \mathrm{~N} \mathrm{~m}$ $\left(\mathrm{M}_{\mathrm{w}}\right.$ 8.5). The average estimated rake value is $106^{\circ}$ or about at the opposite direction to the plate convergence. The calculated

\footnotetext{
${ }^{1}$ Auxiliary materials are available in the HTML. doi:10.1029/ $2010 J B 007565$.
}

seismic moment is very similar to $6.71 \times 10^{21} \mathrm{~N} \mathrm{~m}\left(\mathrm{M}_{\mathrm{w}} 8.5\right)$ obtained by Global CMT solution, while it is slightly larger than $5.15 \times 10^{21} \mathrm{~N}$ m obtained using seismic wave and geodetic data [Konca et al., 2008] and $4.2 \times 10^{21}-4.7 \times 10^{21} \mathrm{~N} \mathrm{~m}$ obtained using tsunami waveform data [Lorito et al., 2008; Fujii and Satake, 2008a].

[38] The observed LOS displacement in the Pagai Islands and the Sumatra Island are used to validate the inferred slip distributions. Figure 7 compares between the observed LOS 

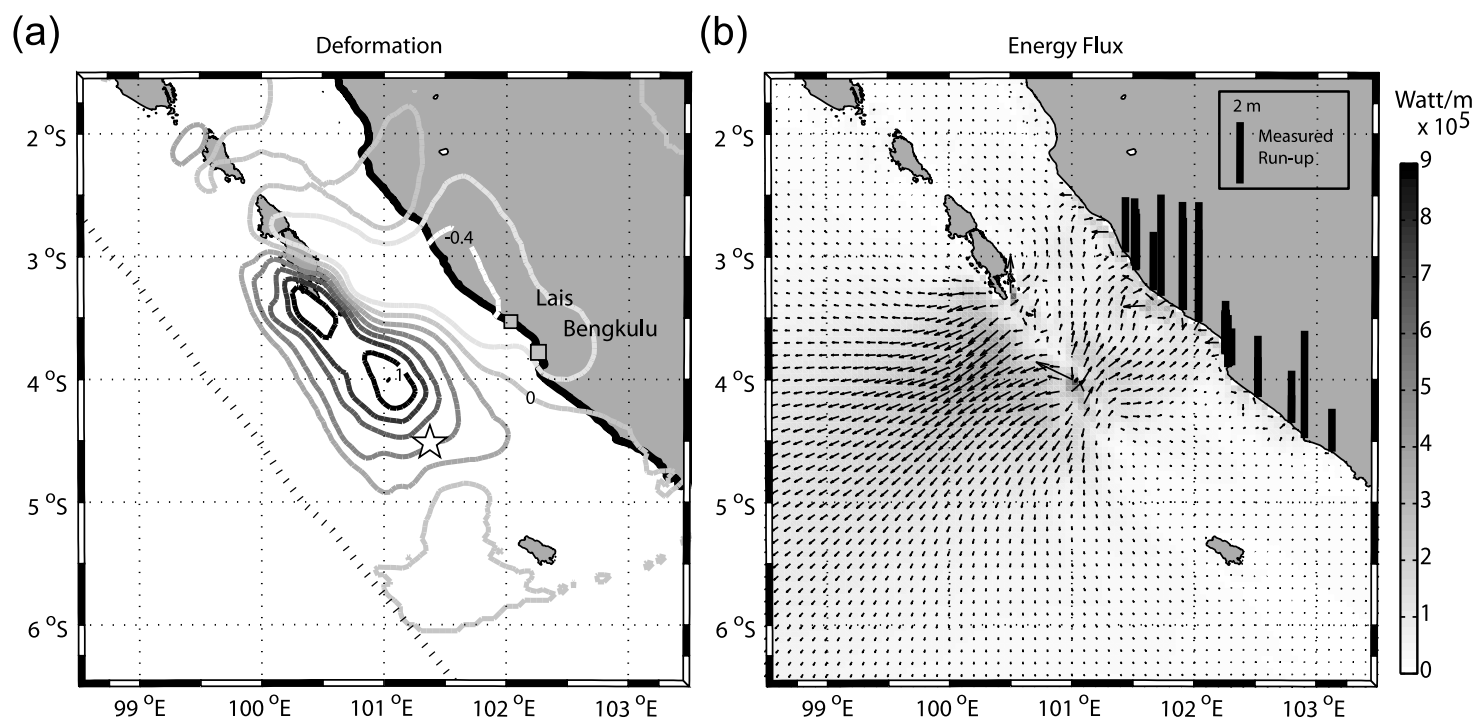

(c)

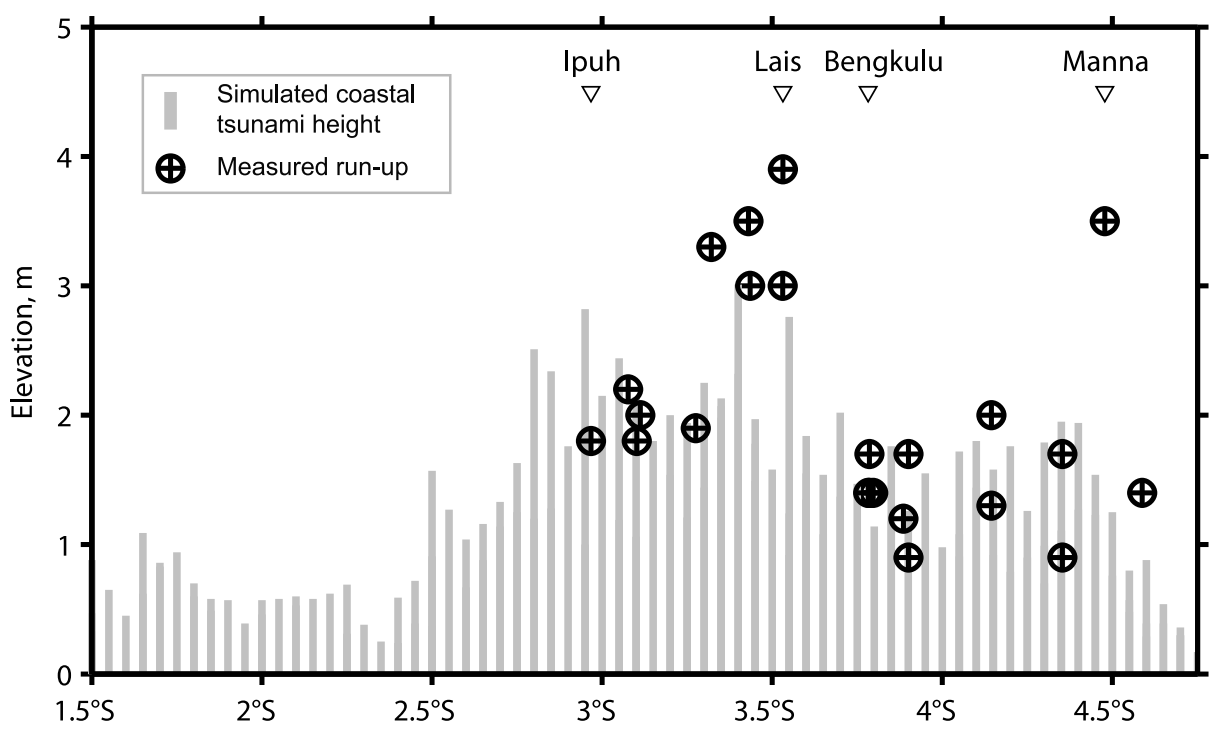

Figure 9. (a) Vertical deformation calculated from the slip distribution of the 2007 Bengkulu earthquake estimated using both tsunami waveforms and InSAR data. (b) Energy flux calculated from the slip distribution estimated by the joint inversion. (c) Measured tsunami runup and simulated coastal tsunami heights from the slip distribution estimated by the joint inversion, along the coastline of Sumatra which is represented by black bold line in Figure 9a.

displacement and that calculated from the result of tsunami waveform inversion. Comparison of the pattern of the fringes on the Pagai Islands shows that the calculated fringes cannot explain the observed ones. The residual between the calculated and observed LOS changes is about $-40 \mathrm{~cm}$ on North Pagai Island and exceeds $80 \mathrm{~cm}$ on south part of South Pagai Island (Figure 7d). Comparison of the pattern of the fringes on Sumatra Island shows that the calculated interferogram from the result of the tsunami waveform inversion does not agree with the observed interferogram (Figures 8a and 8b). The slip distribution inferred from the tsunami waveform inversion thus fails to yield the observed deformation in the Pagai Islands and Sumatra Island. The residuals of the calculated and observed displacement in the LOS direction for the slip distribution estimated from the joint inversion (Figures 7e and 8e) are significantly smaller than those for the slip distribution estimated from the tsunami waveform inversion (Figures $7 \mathrm{~d}$ and $8 \mathrm{~d}$ ).

[39] We calculated standard error of each estimated slip distribution by using Jackknife technique. The maximum error for the slip distribution estimated by the tsunami waveform inversion is about $\pm 0.3 \mathrm{~m}$ (Figure $4 \mathrm{a}$ ), which is relatively small. The slip distribution estimated by the joint inversion is improved with smaller error than that for the tsunami inversion result. The addition of InSAR data significantly reduced the error of slip distribution beneath the 
Pagai Islands (Figure 4b). These results show that the InSAR data strongly constrained a part of slip distribution around the Pagai Islands.

[40] A better slip distribution of the 2007 earthquake should be the one that can explain well more observation data, in this case both the tsunami waveforms and the InSAR data. The simulated tsunami waveforms can explain the observations with almost the same fitness for both of the slip distributions (Figure 6). This result shows that the tsunami waveform inversion provides adequate information for the purpose of understanding the spatial extent of rupture and the location of major slip region. However, the disagreement on the ground displacement between the observations and the calculations suggests that the addition of InSAR data into the joint inversion is important for estimating the slip distribution of the 2007 earthquake in more detail. Hence we consider the joint inversion model is a best estimate of slip distribution of the earthquake.

[41] The vertical deformation on the Pagai Islands due to the main shock of the 2007 Bengkulu earthquake is calculated by using the slip distribution estimated by the joint inversion. The vertical deformation plot (Figure 9a) shows that most of the Pagai Islands were uplifted due to the 2007 Bengkulu earthquake. The maximum uplift of $1 \mathrm{~m}$ is estimated on the south part of South Pagai Island, while for the North Pagai Island the island is subsided about $0.2 \mathrm{~m}$.

\subsection{Near-Field Tsunami}

[42] We compare the measured runups and the simulated tsunami heights along the coastline around Bengkulu in Figure 9c. The slip distribution obtained from the joint inversion produces the tsunami heights which fit to the field data well. The tsunami computation shows that the maximum coastal tsunami heights along coastline of Sumatra to the north of $2.5^{\circ} \mathrm{S}$ are relatively small compared to the south of $2.5^{\circ} \mathrm{S}$.

[43] The surface deformation generated by the slip distribution is elongated from the epicenter to the South Pagai Island. The northern part of initial deformation, shown by Figure 9a, is located in the shallow water region southeast off South Pagai Island and also on the island. The northern part of the sea-surface deformation could not generate large tsunami runup along the Coast of Sumatra Island because of the existence of the Pagai Islands. To the Indian Ocean, large energy flux propagates from both southern and northern parts of the initial sea-surface deformation. The direction of the energy flux is perpendicular to the elongated pattern of the initial sea-surface deformation. The maximum energy flux pattern shows that large energy flux directed toward Lais where the highest runup was measured (Figure 9b).

\section{Discussion}

[44] Previous coral microatoll studies [Natawidjaja et al., 2006; Sieh et al., 2008] revealed that large uplifts occurred on the Mentawai Islands due to the historical great earthquakes in 1797 and 1833. Uplift was as large as $0.8 \mathrm{~m}$ in 1797 and $2.8 \mathrm{~m}$ in 1833 . The source parameters inferred from coral microatolls imply moment magnitudes $\left(\mathrm{M}_{\mathrm{w}}\right)$ of 8.5 to 8.7 and 8.9 for the 1797 and 1833 events, respectively [Natawidjaja et al., 2006]. Revised estimates of the moment released during those events from inversion of geodetic and paleogeodetic data suggests moment magnitude $\left(\mathrm{M}_{\mathrm{w}}\right)$ of 8.7 to 8.9 for the 1797 earthquake and $\mathrm{M}_{\mathrm{w}} 8.9$ to 9.1 for the 1833 earthquake [Chlieh et al., 2008]. Studies from coral microatolls show that the rupture area of the 1797 event extends from the Batu Islands to the Pagai Islands, and the rupture area of the 1833 event extends from Sipora Island to about $150 \mathrm{~km}$ southeast from the Pagai Islands. The 2007 and the historical 1833 great earthquakes appear to have ruptured almost a same plate interface, where the 2007 event rupture a more concentrated interface with smaller slip amounts. The plate interface beneath the Pagai Islands was ruptured at depths between 16 and $36 \mathrm{~km}$ with the maximum slip amount of about $5 \mathrm{~m}$ in the 2007 earthquake. For the 1833 event, the rupture extends all the way to the trench with a slip amount of $18 \mathrm{~m}$ [Natawidjaja et al., 2006]. The coseismic uplift of the 2007 earthquake estimated from the joint inversion is $0.8 \mathrm{~m}$ at the location where the uplift caused by the 1833 event was $2.8 \mathrm{~m}$. The seismic moment of the 2007 event of $6.7 \times 10^{21} \mathrm{~N} \mathrm{~m}$ is as much as $\frac{2}{3}$ or as little as $\frac{1}{8}$ that of the 1833 event, $10 \times 10^{21}-55 \times 10^{21^{3}} \mathrm{~N} \mathrm{~m}$.

[45] Historical accounts of both the 1797 and 1833 events mention about large tsunamis on west coast of Sumatra. In Padang, Dutch and German accounts suggest that the tsunami runup was at least $5 \mathrm{~m}$ but less than $10 \mathrm{~m}$ in 1797 and inundation extended more than $1 \mathrm{~km}$. One account of the 1833 event describes 3 to $4 \mathrm{~m}$ of tsunami runup occurred in Padang. The destruction from the 1883 tsunami was severe in Bengkulu where the pier and custom building were wiped out [Natawidjaja et al., 2006]. The tsunamis at Bengkulu and Padang described in the historical accounts are more severe than those generated by the 2007 great earthquake. The 2007 tsunami runup at the city of Bengkulu was less than $2 \mathrm{~m}$ with minimum damages on its coastal area, where the tsunami overtopped a dock but did not damage the structure [Borrero et al., 2009].

[46] Around Bengkulu, other tsunamis associated with earthquakes are recorded by history in 1770 and 1818. The 1770 earthquake caused severe damage to buildings constructed by the Dutch colonial government in Bengkulu. For 1818 event, people on land were thrown from their bed, suggesting Modified Mercalli Intensity (MMI) IX [Newcomb and McCann, 1987]. An official of the Indonesian Meteorological and Geophysical Agency reported that the 2007 Bengkulu earthquake was felt at V-VI MMI in Bengkulu Province. These similarities suggest that the 1770 and 1818 earthquakes may have resembled the 2007 earthquake in mechanism, location, and size.

[47] There was no historical earthquake in the region with a similar magnitude with the 2007 earthquake after the 1833 great event. The histories of coseismic emergences of coral microatolls between 14th and 19th century suggest that several great earthquakes occurred prior to the great earthquake that ends its supercycle [Sieh et al., 2008]. The moment deficit that has been accumulated since the last great earthquakes in 1797 and 1833 estimated by Chlieh et al., [2008] is far larger than the moment released in 2007. The remains of potential slip must be eventually spent by a single or several future great earthquakes. Therefore the 2007 great earthquake could be followed by several great earthquakes that will rupture the plate interface between the Batu Islands and 
Enggano Island until the potential slip that has been accumulated is completely released.

\section{Conclusions}

[48] We estimated the slip distribution for the 2007 great earthquake $\left(M_{w} 8.5\right)$ by using two types of inversion procedures, which are an inversion using only tsunami waveform data and a joint inversion using both tsunami waveforms and InSAR data. The inversion results show the major slip region for the 2007 Bengkulu earthquake is located on depth between 16 and $36 \mathrm{~km}$. The slip distribution of the 2007 great earthquake determined by the tsunami waveform inversion is similar to that determined by the joint inversion. The fits to the tsunami waveforms from both slip distributions are equally good. However, the result of the tsunami waveform inversion cannot explain the ground deformation in both the Pagai Islands and Sumatra Island. The addition of InSAR data into the joint inversion is important for constraining the slip distribution of the 2007 earthquake in more detail.

[49] The seismic moment calculated from the slip distribution is $6.7 \times 10^{21} \mathrm{~N} \mathrm{~m}\left(\mathrm{M}_{\mathrm{w}} 8.5\right)$. The calculated seismic moment is similar to $6.71 \times 10^{21} \mathrm{~N} \mathrm{~m}\left(\mathrm{M}_{\mathrm{w}} 8.5\right)$ obtained by Global CMT solution, while it is slightly larger than that obtained using seismic wave and geodetic data [Konca et al., 2008] and those obtained using tsunami waveform data [Lorito et al., 2008; Fujii and Satake, 2008a].

[50] Comparison of the measured runups with the calculated maximum coastal tsunami heights from the slip distribution shows good agreement. The tsunami numerical simulation shows that the northern part of sea-surface deformation could not generate high tsunami on main island of Sumatra because the deformation is located on a shallow water region and some part occurred on land. The energy flux pattern shows that the energy propagated toward and focused on around Lais where the highest tsunami runup was measured.

[51] Historical records show that both the 1797 and 1833 earthquakes generated large destructive tsunamis [Natawidjaja et al., 2006]. Both events are more severe than the tsunami generated by the 2007 event. Other historical events of the 1770 and 1818 generated tsunamis near Bengkulu. These events occurred before the culminating 1833 great earthquake and may be similar underthrust earthquakes to the 2007 Bengkulu event.

[52] The moment released in 2007 is far smaller than the moment deficit that has been accumulated since the last great earthquakes in 1797 and 1833 . The remains of potential slip must be eventually spent by a single or several future great earthquakes. Therefore the 2007 great earthquake could be followed by several great earthquakes that will rupture the plate interface between the Batu Islands and Enggano Island until the potential slip that has been accumulated is completely released.

[53] Acknowledgments. PALSAR level-1.0 data were provided from the Earthquake Working Group under a cooperative research contract with JAXA (Japan Aerospace Exploration Agency). The ownership of PALSAR data belongs to METI (Ministry of Economy, Trade and Industry) and JAXA. We thank Robert Nowack for a review, an anonymous associate editor, Brian Atwater, and an anonymous reviewer for their helpful comments and suggestions.

\section{References}

Akaike, H. (1980), Likelihood and the Bayes procedure, in Bayesian Statistics, edited by J. M. Bernando et al., pp. 143-166, Univ. Press, Valencia, Spain.

Ammon, C. J., et al. (2005), Rupture process of the 2004 Sumatra-Andaman earthquake, Science, 308, 1133-1139, doi:10.1126/science.1112260.

Baba, T., and P. R. Cummins (2005), Contiguous rupture areas of two Nankai Trough earthquakes revealed by high-resolution tsunami waveform inversion, Geophys. Res. Lett., 32, L08305, doi:10.1029/ 2004GL022320

Borrero, J. C. (2005), Field survey of northern Sumatra and Banda Aceh, Indonesia after the tsunami and earthquake of 26 December 2004, Seismol. Res. Lett., 308, 312-320.

Borrero, J. C., R. Weiss, E. A. Okal, R. Hidayat, D. Arcas Suranto, and V. V. Titov (2009), The tsunami of 2007 September 12, Bengkulu province, Sumatra, Indonesia: Post-tsunami field survey and numerical modelling, Geophys. J. Int., 178, 180-194, doi:10.1111/j.1365-246X.2008.04058.x.

Briggs, R. W., et al. (2006), Deformation and slip along the Sunda Megathrust in the great 2005 Nias-Simeulue earthquake, Science, 311, 1897 , doi:10.1126/science. 1122602

Bürgmann, R., P. A. Rosen, and E. J. Fielding (2000), Synthetic aperture radar interferometry to measure Earth's surface topography and its deformation, Annu. Rev. Earth Planet. Sci., 28, 169-209.

Chlieh, M., et al. (2007), Coseismic slip and afterslip of the great Mw 9.15 Sumatra-Andaman earthquake of 2004, Bull. Seismol. Soc. Am., 97, S152-S173, doi:10.1785/0120050631.

Chlieh, M., J.-P. Avouac, K. Sieh, D. H. Natawidjaja, and J. Galetzka (2008), Heterogeneous coupling of the Sumatran megathrust constrained by geodetic and paleogeodetic measurements, J. Geophys. Res., 113, B05305, doi:10.1029/2007JB004981.

Diament, M., H. Harjono, K. Karta, C. Deplus, D. Dahrin, M. T. Zen Jr M. Gerard, O. Lassal, A. Martin, and J. Malod (1992), Mentawai fault zone off Sumatra: A new key to the geodynamics of western Indonesia, Geology, 20, 259-262.

Farr, T. G., et al. (2007), The Shuttle Radar Topography Mission, Rev. Geophys., 45, RG2004, doi:10.1029/2005RG000183.

Fujii, Y., and K. Satake (2008a), Tsunami waveform inversion of the 2007 Bengkulu, southern Sumatra, earthquake, Earth Planets Space, 60 993-998.

Fujii, Y., and K. Satake (2008b), Tsunami sources of the November 2006 and January 2007 great Kuril earthquakes, Bull. Seismol. Soc. Am., 98 , 1559-1571, doi:10.1785/0120070221.

Fujii, Y., and K. Satake (2007), Tsunami source of the 2004 SumatraAndaman earthquake inferred from tide gauge and satellite data, Bull. Seism. Soc. Am., 97, S192-S207, doi:10.1785/0120050613.

Geist, E. L., V. V. Titov, D. Arcas, F. F. Pollitz, and S. L. Bilek (2007), Implications of the 26 December 2004 Sumatra-Andaman Earthquake on tsunami forecast and assessment models for great subduction-zone earthquakes, Bull. Seismol. Soc. Am., 97, S249-S270.

Genrich, J. F., Y. Bock, R. McCaffrey, L. Prawirodirdjo, C. W. Stevens, S. S. O. Puntodewo, C. Subarya, and S. Wdowinski (2000), Distribution of slip at the northern Sumatran fault system, J. Geophys. Res., 105(B12), 28,327-28,341.

Goff, J. R., P. L. F. Liu, B. Higman, R. Morton, B. E. Jaffe, H. Fernando, P. Lynett, H. M. Fritz, C. E. Synolakis, and S. Fernando (2006), Sri Lanka field survey after the December 2004 Indian Ocean tsunami, Earthquake Spectra, 22, S155-S172.

Jaffe, B. E., et al. (2006), Northwest Sumatra and offshore islands field survey after the December 2004 Indian Ocean tsunami, Earthquake Spectra, 22, S105-S135.

Jankaew, K., B. F. Atwater, Y. Sawai, M. Choowong, T. Charoentitirat, M. E. Martin, and A. Prendergast (2008), Medieval forewarning of the 2004 Indian Ocean tsunami in Thailand, Nature, 455, 1228-1231, doi:10.1038/nature 07373

Ji, C., D. J. Wald, and D. V. Helmberger (2002), Source description of the 1999 Hector Mine, California, earthquake, Part I: Wavelet domain inversion theory and resolution analysis, Bull. Seismol. Soc. Am., 92, 1192-1207

Johnson, J. M. (1999), Heterogeneous coupling along Alaska-Aleutians as inferred from tsunami, seismic, and geodetic inversions, Adv. Geophys., $39,1-116$.

Jónsson, S., H. Zebker, P. Segall, and F. Amelung (2002), Fault slip distribution of the $1999 \mathrm{Mw} 7.1$ Hector Mine, California, earthquake, estimated from satellite radar and GPS measurements, Bull. Seismol. Soc. Am., 92, 1377-1389.

Konca, A. O., et al. (2008), Partial rupture of a locked patch of the Sumatra megathrust during the 2007 earthquake sequence, Nature, 456, 631-635, doi:10.1038/nature07572. 
Kowalik, Z., J. Horrillo, W. Knight, and T. Logan (2008), Kuril Islands tsunami of November 2006: 1. Impact at Crescent City by distant scattering, J. Geophys. Res., 113, C01020, doi:10.1029/2007JC004402.

Lay, T., et al. (2005), The great Sumatra-Andaman earthquake of 26 December 2004, Science, 308, 1127-1133, doi:10.1126/science.1112250.

Lay, T., C. J. Ammon, A. R. Hutko, and H. Kanamori (2010), Effects of kinematic constraints on teleseismic finite-source rupture inversions: Great Peruvian earthquakes, Bull. Seismol. Soc. Am., 100, 969-994, doi: $10.1785 / 0120090274$.

Liu, P. L. F., P. Lynett, H. Fernando, B. E. Jaffe, H. M. Fritz, B. Higman, R. Morton, J. R. Goff, and C. E. Synolakis (2005), Observations by the International Tsunami Survey Team in Sri Lanka, Science, 308, 1595.

Lorito, S., F. Romano, A. Piatanesi, and E. Boschi (2008), Source process of the September 12, 2007, MW 8.4 southern Sumatra earthquake from tsunami tide gauge record inversion, Geophys. Res. Lett., 35, L02310, doi:10.1029/2007GL032661.

Massonnet, D., and K. L. Feigl (1998), Radar interferometry and its application to changes in the Earth's surface, Rev. Geophys., 36, 441-500.

Monecke, K., W. Finger, D. Klarer, W. Kongko, B. G. McAdoo, A. L. Moore, and S. U. Sudrajat (2008), A 1,000-year sediment record of tsunami recurrence in northern Sumatra, Nature, 455, 1232-1234, doi:10.1038/nature 07374 .

Natawidjaja, D. H., K. Sieh, M. Chlieh, J. Galetzka, B. W. Suwargadi, H. Cheng, R. L. Edwards, J.-P. Avouac, and S. N. Ward (2006), Source parameters of the great Sumatran megathrust earthquakes of 1797 and 1833 inferred from coral microatolls, J. Geophys. Res., 111, B06403, doi:10.1029/2005JB004025

Newcomb, K. R., and W. R. McCann (1987), Seismic history and seismotectonics of the Sunda Arc, J. Geophys. Res., 92(B1), 421-439.

Okada, Y. (1985), Surface deformation due to shear and tensile faults in half-space, Bull. Seismol. Soc. Am., 75-4, 1135-1154.

Ruff, L. J. (1992), Asperity distributions and large earthquake occurrence in subduction zones, Tectonophysics, 211, 61-83.

Samet, H., and R. E. Webber (1988), Hierarchical data structures and algorithms for computer graphics, part I: Fundamentals, IEEE Comput. Graphics. Appl., 8(3), 48-68.

Satake, K. (1989), Inversion of tsunami waveforms for the estimation of heterogeneous fault motion of large submarine earthquakes: The 1968 Tokachi-oki and 1983 Japan sea earthquake, J. Geophys. Res., 94(B5), 5627-5636.

Sieh, K., and D. H. Natawidjaja (2000). Sumatran fault neotectonics, J. Geophys. Res., 105(B12), 28,295-28,326.

Sieh, K., D. H. Natawidjaja, A. J. Meltzner, C-C. Shen, H. Cheng, K-S. Li, B. W. Suwargadi, J. Galetzka, B. Philibosian, and R. L. Edwards (2008).
Earthquake supercycles inferred from sea-level changes recorded in the corals of West Sumatra, Science, 322, 1674-1678, doi:10.1126/science. 1163589.

Synolakis, C. E., E. N. Bernard, V. V. Titov, U. Kânoğlu, and F. I. González (2008), Validation and verification of tsunami numerical models, Pure Appl. Geophys., 165, 2197-2228, doi:10.1007/s00024-004-0427-y.

Tanioka, Y., L. Ruff, and K. Satake (1995), The great Kurile earthquake of October 4, 1994 tore the slab, Geophys. Res. Lett., 22, 1661-1664.

Tichelaar, B. W., and L. J. Ruff (1989). How good are our best models?, Eos Trans. $A G U, 70,593,605-606$.

Titov, V., A. B. Robinovich, H. O. Mofjeld, R. E. Thomson, and F. I. Gonzalez (2005), The global reach of the 26 December 2004 Sumatra tsunami, Science, 309, 2045-2048.

Tsuji, Y., Y. Namegaya, H. Matsumoto, S. Iwasaki, W. Kanbua, M. Sriwichai, and V. Meesuk (2006), The 2004 Indian tsunami in Thailand: surveyed runup heights and tide gauge records, Earth Planets Space, 58, 223-232.

Wegmüller, U., and C. L. Werner (1997), Gamma SAR processor and interferometry software, in Proceedings of the 3rd ERS Symposium, Eur. Space Agency Spec. Publ., ESA SP-414, 1687-1692.

Yabuki, T., and M. Matsu'ura (1992), Geodetic data inversion using Bayesian information criterion for spatial distribution of fault slip, Geophys. J. Int., 109, 363-375.

Yeh, H., C. Peterson, R. K. Chadha, G. Latha, and T. Katada (2005), The great Sumatra Earthquake and Indian Ocean tsunami of December 26, 2004, Report 2: Tsunami survey along the southeast Indian Coast, Special Earthquake Report, Earthquake Eng. Res. Inst., Oakland, Calif

Zebker, H.A., and J. Villasenor (1992), Decorrelation in interferometric radar echoes, IEEE Trans. Geosci. Remote Sens., 30, 950-959.

A. R. Gusman and Y. Tanioka, Institute of Seismology and Volcanology, Hokkaido University, N10W8 Kitaku, Sapporo, Hokkaido, 060-0810, Japan. (adit@mail.sci.hokudai.ac.jp; tanioka@mail.sci.hokudai.ac.jp)

T. Kobayashi, Geospatial Information Authority of Japan, 1 Kitasato, Tsukuba, Ibaraki, 305-0811, Japan. (tkoba@gsi.go.jp)

H. Latief, Department of Oceanography, Bandung Institute of Technology, Jalan Ganesha 10, Bandung, 40132, Indonesia. (hamzah@ ppk.itb.ac.id)

W. Pandoe, Agency of the Assessment and Application of Technology, Jalan M. H. Thamrin 8, Jakarta, 10340, Indonesia. (wpandoe@webmail. bppt.go.id) 